\title{
¿QUÉ HAGO CON LOS ERASMUS?
}

\author{
Juan A. RÍOS CARRATALÁ \\ Universidad de Alicante
}

¿Cómo se debe enfocar la explicación de un tema dedicado a la obra de García Lorca o Buero Vallejo cuando la mayoría del alumnado procede de los más distantes países? No hablo de una hipótesis, sino de una realidad que constato cada curso al pasar lista a los matriculados en mi asignatura de Historia del teatro español del siglo XX. El resultado se repite desde hace varios años: apenas cuento con una quinta parte de alumnos nacionales. El resto son Erasmus de Italia, Francia, Polonia, Holanda, Austria... que estudian en sus países distintas licenciaturas no siempre relacionadas con la Filología y que, además, se ven acompañados en clase por alumnos norteamericanos dispuestos a "tomar" mi asignatura por razones que se me escapan. El problema es encontrar un denominador común capaz de interesar a la mayoría y que resulte comprensible. No es fácil, lo puedo asegurar por experiencia.

El sentido común suele resultar un excelente guía docente en estos casos. Hace tiempo que dejé de empeñarme en explicar una verdadera historia del teatro español del siglo XX. Soy agnóstico y, por lo tanto, no creo en el milagro de que alguien en cuatro meses pase de no saber nada al respecto, ni siquiera a veces el idioma, a poder examinarse de una materia tan específica. Me conformo con que lean en sus casas y vean en clase una breve y significativa selección de obras. El objetivo es que tengan una mínima experiencia como lectores y espectadores a partir de unos títulos que, al margen de sus indiscutibles valores teatrales, les permitan conocer las grandes líneas de la historia reciente de un país donde viven, temporalmente, sin apenas conocer su pasado. Lo mismo cabe decir de los alumnos españoles.

El cine es una gran ayuda en este caso. En primer lugar, porque contamos con unas adaptaciones cinematográficas que suplen la habitual ausencia o falta de accesibilidad de las representaciones teatrales grabadas en vídeo o DVD ${ }^{1}$. Son películas

\footnotetext{
${ }^{1}$ Si la selección de títulos cinematográficos en el mercado del DVD responde a unos criterios no siempre comprensibles para el profano, en el caso de los teatrales la orientación es más clara: su desaparición. Buena parte de las obras registradas y comercializadas en VHS no han pasado al nuevo formato, sin que
} 
desiguales con un tratamiento siempre discutible del texto original. Ya examiné pormenorizadamente este tema en libros como El teatro en el cine español, La ciudad provinciana: Literatura y cine en torno a Calle Mayor y Dramaturgos en el cine español (1939-1975), que surgieron del trabajo realizado en clase durante varios cursos. Mantengo lo afirmado en esas páginas, rechazo cualquier purismo y sigo convencido de que es preferible una buena adaptación cinematográfica a una regular representación teatral del texto elegido para el temario. Lo he comprobado en varias ocasiones con mis alumnos, a quienes siempre procuro informar de las razones que motivan las posibles discordancias entre la obra y su versión cinematográfica. En segundo lugar, esas películas a menudo me permiten algo fundamental en el programa del curso: dar imágenes potentes, plenas de significado, para vislumbrar una idea de lo que fue España durante el siglo XX. Una idea parcial, incompleta y superficial; de acuerdo, pero con un horizonte temporal de cuatro meses conviene no perderse en objetivos inalcanzables y me conformo con sugerir lo imprescindible con la confianza de que los buenos alumnos, los hay, profundicen en esa línea a lo largo de su formación académica.

Cada año selecciono obras teatrales y adaptaciones cinematográficas que nos hablen de aspectos fundamentales de una España que los Erasmus desconocen, mientras que los alumnos españoles la ignoran en su inmensa mayoría. En este punto, como en tantos otros, coinciden, aunque por motivos distintos. Una de esas obras es Las bicicletas son para el verano (1977), de Fernando Fernán-Gómez, con la homónima adaptación dirigida por Jaime Chávarri en 1983. Gracias a esos materiales, podemos hablar en clase de lo que supuso la experiencia de la guerra civil, rememorada desde una perspectiva que la hace semejante a cualquier otra guerra contemporánea. En la España de 1936 o en la Europa de pocos años después hubo muchas familias que, como la recreada por Fernando Fernán-Gómez, vieron fatalmente interrumpida su cotidianidad, sustituida por otra de carácter extraordinario y resultados tan inciertos como a menudo trágicos. Recuerdo a mis alumnos la existencia de algunos elementos específicos de lo que significó el enfrentamiento bélico propiciado por el golpe de Estado del 18 de julio de 1936. Conviene evitar equiparaciones que hagan caso omiso de lo que diferencia cada acontecimiento histórico, pero me resulta sencillo explicar el miedo a un bombardeo, la ilusión de futuro frustrada por la violenta irrupción de la Historia en la historia particular de cada personaje, el hambre de una ciudad sitiada, el afán de 
sobrevivir a cualquier precio, el relativo valor de las ideas o los valores cuando las necesidades acucian, la camaleónica capacidad de adaptación a unas realidades poco antes consideradas como inimaginables... Son experiencias universales, fácilmente comprensibles por alumnos que pueden pensar en otras guerras de sus respectivos países.

Al finalizar las clases dedicadas a Las bicicletas son para el verano y su adaptación cinematográfica, suelo preguntar a mis alumnos acerca del futuro que les espera a sus protagonistas en la España de la Victoria franquista. También lo hacían muchos de los espectadores que asistieron al estreno teatral de 1982. Mostraban así su grado de identificación con unos personajes a los que suponían vivos más allá del escenario. Se trata en mi caso de una pregunta retórica, sin apenas posibilidad de ser contestada salvo que se conozca lo fundamental de la dictadura militar y eclesiástica iniciada en 1939. Casi ningún alumno se atreve a aventurar una respuesta, aunque son conscientes del dramatismo de la situación. Tengo que contestarla yo mismo, apoyándome en un texto de Fernando Fernán-Gómez escrito poco después del estreno de la obra y que relata las andanzas de los protagonistas en la España franquista ${ }^{2}$. Suele ser un buen ejercicio para la lógica y la imaginación, pero desde el primer año que lo puse en práctica percibí que a muchos alumnos, españoles y extranjeros, les costaba concebir un país tan brutal y cainita. No me extraña, pues todo lo relacionado con la posguerra parece un tanto irreal desde nuestra acomodada perspectiva, hasta grotesco a veces con su correspondiente componente risible. Y no es la risa, precisamente, la reacción que provoca el conocimiento de una época negra que todavía no ha sido asumida por una sociedad española bastante reacia a la memoria histórica.

Desde el primer año que incluí Las bicicletas son para el verano en el temario, pensé que sería conveniente completar el tema con alguna película que nos hablara de la posguerra. Y que lo hiciera, además, en un tono coherente con la obra teatral de Fernando Fernán-Gómez, aportando imágenes y sensaciones de difícil olvido. Pronto pensé que la elección más adecuada era Canciones para después de una guerra (19711975), de Basilio Martín Patiño. La experiencia ha sido interesante y positiva, tanto para los alumnos españoles como para los Erasmus. A los primeros les sorprende que las imágenes tan hábilmente seleccionadas y montadas les hablen de su propio país. No lo reconocen, ni siquiera lo imaginan como el de sus abuelos, porque han tenido

\footnotetext{
2 “QQué fue de aquella gente?”, en Fernando FERNÁN-GÓMEZ, Las bicicletas son para el verano, ed. Manuel Aznar Soler y J. Ramón López García, Barcelona, Vicens Vives, 1996, pp. 173-186.
} 
escasísimas oportunidades de ver este tipo de películas. Tal vez les haya faltado curiosidad intelectual para buscarlas, pero me alarma que nuestro sistema educativo sea tan limitado en lo referente a la recuperación de la memoria histórica. Los Erasmus también se sorprenden porque les parece que se trata de otro país, apenas ven nexos de unión con el que ellos acaban de conocer. Me interesa mucho esta reacción. No porque intente algo tan absurdo como desmentir lo que ven sus propios ojos, sino porque la oportunidad de estudiar en otro país debe implicar un mínimo de familiaridad con su historia. Ellos viajan por una Europa unida en lo básico, pero la España autárquica y dictatorial estuvo muy lejos de esa Europa.

En el caso de Canciones para después de una guerra lo primero que subrayan los Erasmus es el contraste con el presente que han conocido. Un presente que les resulta familiar, sin apenas sorpresas que vayan más allá de lo anecdótico de unas cuantas costumbres nacionales convertidas en tópicos de conversación. Al ver en clase algunas imágenes de la posguerra y sus correspondientes canciones, intento contextualizarlas y justificarlas en su marco histórico. Los Erasmus toman apuntes con la celeridad de los alumnos aplicados, pero durante las tutorías, cuando intento dialogar con ellos para aclarar algo del misterio que supone el rostro anónimo de quien atiende a tus explicaciones, los más inquietos me preguntan por el abismo que separa el franquismo de la España actual. Un abismo observado con la curiosidad que despierta lo desconocido y un tanto insólito.

No obstante, los Erasmus también se sorprenden al ver imágenes de soldados alemanes e italianos combatiendo en nuestro país, al saber de las Brigadas Internacionales, cuando les comento el cierre de las fronteras con Francia y la falta de ayuda de las potencias democráticas, el exilio primero político y luego económico de tantos españoles..., un sinfín de circunstancias sacadas a colación gracias a las imágenes del documental y que les aportan una información que tampoco se les había dado en sus países. Me he encontrado con alumnos procedentes del sur de Francia que nada sabían sobre los campos de concentración donde acabaron tantos republicanos en 1939, italianos sorprendidos al conocer que más de setenta mil compatriotas combatieron en el bando del general Franco, alemanes que ignoraban la existencia de la Legión Cóndor, norteamericanos ajenos al más remoto conocimiento de lo que supuso su país para el fin del aislamiento de la dictadura, incluso a algún argentino sorprendido al ver a Isabel Perón junto al dictador en olor de masas porque traía trigo y carne. La sorpresa es, en definitiva, que una película programada para informales de lo sucedido 
en la España de la posguerra también les acaba hablando de sus países, supongo que renuentes como el nuestro a la hora de asumir episodios tan históricos como ahora impresentables.

La película de Basilio Martín Patiño también me permite hablar de los cambios que afectan al significado de las imágenes, de cómo unos materiales creados para la exaltación de un régimen pueden convertirse en involuntarios testimonios para su crítica. Comprobamos así que las imágenes no son unívocas gracias a la sabiduría del citado director y que, a veces, sintetizan todo un período histórico cuyo conocimiento requiere otras fuentes. Los Erasmus apenas permanecen unos meses en España y resulta difícil imaginar que accedan a esas fuentes, pero al menos se llevan esas imágenes y sus canciones, como el luto de Bernarda Alba, el casino provinciano donde la señorita de Trevélez es burlada, el paseo nocturno de Max Estrella, las peripecias de Carmela y Paulino en el frente de Aragón, las dudas de Dionisio a la hora de elegir un sombrero de copa... Tal vez el resultado sea disperso, más acumulativo que razonado, pero se trata de una asignatura cuatrimestral donde todo ha de ser fugaz. Sólo cabe confiar en haber despertado la curiosidad de los mejores alumnos y que alguno de ellos, de vuelta a sus países, indague en una dirección cercana, a la búsqueda de una memoria histórica que también será la suya.

Cuando los profesores hablamos de los Erasmus, casi siempre sale a colación el problema del idioma y ya se han arbitrado respuestas docentes para solventarlo. Pero también hay otra carencia no menos importante: la de un imaginario que les permita observar nuestro país desde una perspectiva histórica y contrastada. El cine, documental o de ficción, puede ser una buena solución. Estoy convencido de que en cada universidad española convendría programar un curso complementario dedicado a esta necesidad, que también es perceptible cuando hablamos de los alumnos españoles igualmente sujetos a un panorama cultural donde sólo se conjuga en presente. Basta con una buena selección de películas y la voluntad de establecer un diálogo a partir de ellas. Las sorpresas, lo digo por experiencia, pueden ser numerosas y los resultados enriquecerían una estancia en España de los Erasmus que debería ser un punto de partida para posteriores acercamientos a nuestra cultura e Historia. 


\section{BIBLIOGRAFÍA:}

FERNÁN-GÓMEZ, Fernando (1977), Las bicicletas son para el verano, ed. Manuel Aznar Soler y J. Ramón López García, Barcelona, Vicens Vives, 1996.

RÍOS CARRATALÁ, Juan A., El teatro en el cine español, Alicante, Secretariado de Publicaciones de la Universidad de Alicante, 2000.

, La ciudad provinciana. Literatura y cine en torno a Calle Mayor, Alicante, Secretariado de Publicaciones de la Universidad de Alicante, 2001.

_. Dramaturgos en el cine español, 1939-1975, Alicante, Secretariado de Publicaciones de la Universidad de Alicante, 2003. 